\title{
Extreme IOD induced tropical Indian Ocean warming in 2020
}

Ying Zhang ${ }^{1,2}$ and Yan Du 1,2,3* $^{*}$

\begin{abstract}
The tropical Indian Ocean (TIO) basin-wide warming occurred in 2020, following an extreme positive Indian Ocean Dipole (IOD) event instead of an El Niño event, which is the first record since the 1960s. The extreme 2019 IOD induced the oceanic downwelling Rossby waves and thermocline warming in the southwest TIO, leading to sea surface warming via thermocline-SST feedback during late 2019 to early 2020. The southwest TIO warming triggered equatorially antisymmetric SST, precipitation, and surface wind patterns from spring to early summer. Subsequently, the cross-equatorial "C $\mathrm{C}$-shaped" wind anomaly, with northeasterly-northwesterly wind anomaly north-south of the equator, led to basin-wide warming through wind-evaporation-SST feedback in summer. This study reveals the important role of air-sea coupling processes associated with the independent and extreme IOD in the TIO basin-warming mode, which allows us to rethink the dynamic connections between the Indo-Pacific climate modes.
\end{abstract}

Keywords: Indian Ocean Basin warming, Indian Ocean Dipole, Downwelling Rossby waves, Southwest tropical Indian Ocean

\section{Introduction}

The Indian Ocean Basin (IOB) mode is the first mode of the interannual variability of sea surface temperature in the tropical Indian Ocean (TIO), which is characterized by basin-warming/cooling (Klein et al. 1999; Yang et al. 2007). The IOB shows a close tie with El Niño-Southern Oscillation (ENSO), which develops during the mature phase of ENSO, reaches its peak in the following spring and persists into summer (Klein et al. 1999; Yu and Lau 2005; Du et al. 2009). IOB evolution involves active airsea interactions over the TIO with important impacts on the surrounding climate rather than a passive response to ENSO (Yang et al. 2007; Xie et al. 2009, 2016; Du et al. 2011; Hu et al. 2011, 2012; $\mathrm{Hu}$ and Duan 2015; Huang et al. 2011, 2016; Chowdary et al. 2019). A "capacitor effect" proposed by Yang et al. (2007) and Xie et al. (2009) reveals that the TIO basin-warming acts as a capacitor,

\footnotetext{
*Correspondence: duyan@scsio.ac.cn

${ }^{1}$ State Key Laboratory of Tropical Oceanography, South China Sea Institute of Oceanology, Chinese Academy of Sciences, Guangzhou, China

Full list of author information is available at the end of the article
}

being charged up by El Niño, anchoring atmospheric anomalies over the Indo-Pacific Oceans, and exerting climate influences like a discharging capacitor (Xie et al. 2016).

The physical processes, including the air-sea feedbacks associated with the atmospheric bridge (Lau and Nath 1996; Klein et al. 1999) and the ocean dynamic effect (Masumoto and Meyers 1998; Huang and Kinter 2002; Xie et al. 2002) are responsible for the development of IOB.

The "atmospheric bridge" mechanism is caused by the ENSO-induced Walker Circulation anomalies, which affect sea surface temperature (SST) in the TIO via cloud-radiation-SST feedback and wind-evaporationSST (WES) feedback (Lau and Nath 1996; Klein et al. 1999; Reason et al. 2000; Alexander et al. 2002). The atmospheric circulation and convection weaken over the TIO during El Niño, accompanying the reduction of cloud cover and winds, leading to an increase in the solar radiation absorbed by the ocean and a decrease in the heat latent flux loss of the ocean, thereby resulting in the SST warming in the TIO. However, the warming in 
the southwest TIO (SWTIO) cannot be explained by the air-sea interface fluxes. Instead, the importance of ocean dynamics has been discovered and emphasized in previous studies (Murtugudde and Busalacchi 1999; Chambers et al. 1999; Murtugudde et al. 2000; Behera et al. 2000; Huang and Kinter 2002; Xie et al. 2002; Du et al. 2021).

A thermocline dome in the SWTIO is maintained by the upwelling induced by negative wind curl between the weak equatorial westerlies and the southeasterly trades (Hermes and Reason 2008; Yokoi et al. 2008), which provides a favorable condition for subsurface temperature variability to affect SST (e.g., Neelin et al. 1998; Xie et al. 2002). An anticyclonic atmospheric circulation appears over the southern TIO during an El Niño event, which forces westward-propagating downwelling Rossby waves (Masumoto and Meyers 1998; Yu et al. 2005; Tozuka et al. 2010). The westward-propagating downwelling Rossby waves deepen the thermocline depth and cause the thermocline warming in the thermocline dome region, resulting in SST warming, which is called thermocline-SST feedback (Xie and Philander 1994). Thus, the SST warming in the SWTIO can sustain through the summer even as El Niño dissipates (Xie et al. 2002; Annamalai et al. 2005), which induces an increase in atmospheric convection and precipitation over the southern TIO (Wu et al. 2008; Wu and Yeh, 2010). A cross-equatorial "C-shaped" wind anomaly, with northeasterly-northwesterly wind anomaly north-south of the equator, results from the SWTIO warming-induced SST gradient between the north and south and the reverse of the Coriolis force across the equator (Kawamura et al. 2001; Wu et al. 2008;
Wu and Yeh 2010; Chakravorty et al. 2013). In the early spring, the northeasterly wind anomaly enhances the winter monsoon over the north Indian Ocean, which cools down the SST through negative WES feedback. The northeasterly anomaly persists into the summer due to the long-lasting SWTIO warming and weakens the summer southwesterly monsoon, thus leading to a second SST warming north of the equator due to reduction of latent heat flux (Du et al. 2009, 2013). The equatorially asymmetric SST and wind anomalies are critical to maintaining basin-wide warming in the TIO until summer (Du et al. 2009; Guo et al. 2018).

The basin-wide warming in the TIO is found to be stronger during co-occurrence of El Niño and Indian Ocean Dipole (IOD) than that during El Niño only (Chowdary and Gnanaseelan 2007; Hong et al. 2010). The air-sea feedbacks associated with ENSO-induced atmospheric bridges play an important role in the persistence of basin-wide warming in the TIO during the pure El Niño years. During El Niño and IOD co-occurrence years, air-sea feedbacks and ocean dynamics are of great importance for the TIO basin warming. However, such basin-wide warming is not seen during pure IOD years due to the absence of ENSO-induced subsidence over the eastern TIO (Chowdary and Gnanaseelan 2007; Chakravorty et al. 2014).

Basin-wide warming occurred in the TIO in 2020, which followed an extreme positive IOD instead of an El Niño event (Fig. 1a). This is the first record since the 1960s. The 2020 IOB warming caused devastating flooding in Japan and central China associated with the heavy
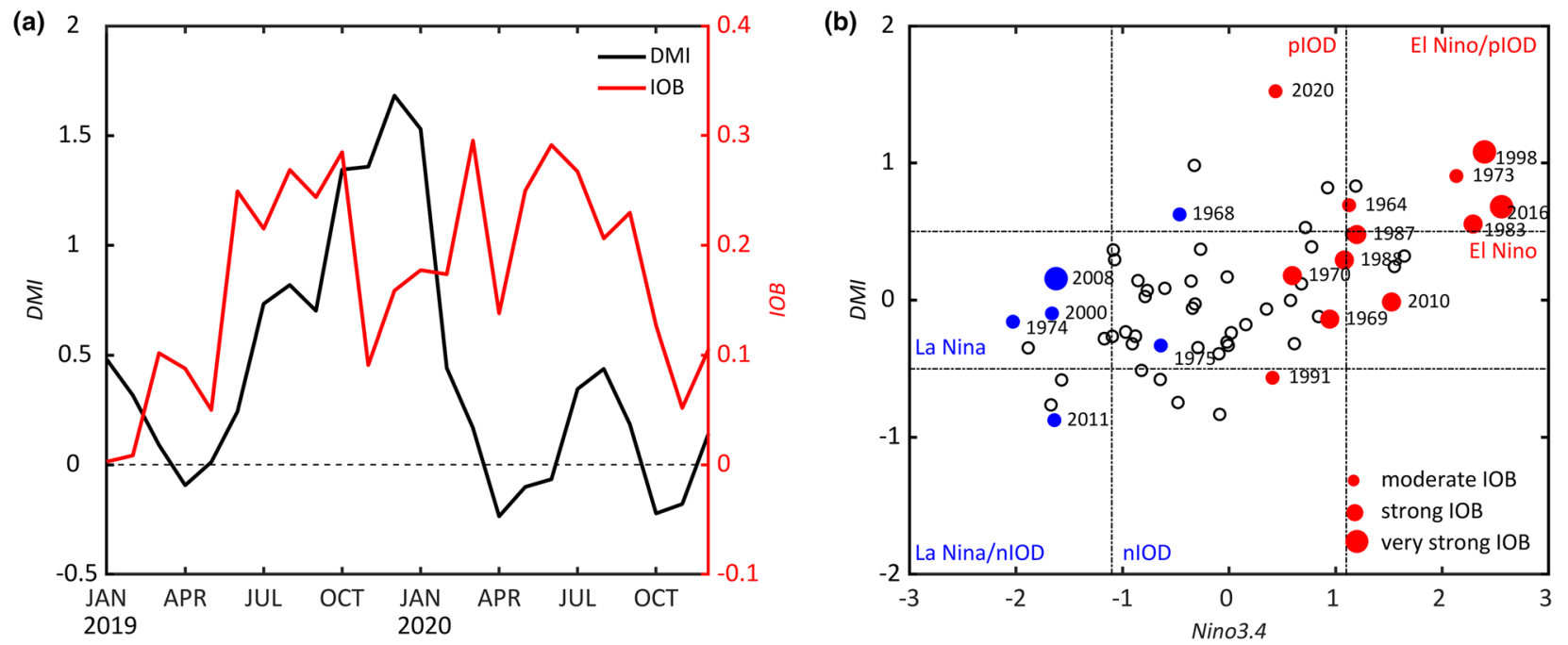

Fig. 1 a Time series of the Indian Ocean dipole mode index (DMI) and IOB mode index during Jan 2019-Dec 2020. b Scatter plot between DMI and Niño3.4 index, superimposed with following-year IOB events (red and blue dots). Small, medium and large red (blue) dots represent IOB index exceed (-) 1, 1.5, and 2 std of IOB index, respectively 
Meiyu-Baiu precipitation (Zhou et al. 2021; Takaya et al. 2020). However, it is not fully understood the dynamic processes of IOB in 2020 that followed an IOD rather than an El Niño event, which is the goal of this study.

\section{Data}

In this study, the NOAA Optimum Interpolation (OI) Sea Surface Temperature (SST) version 2 monthly fields (Reynolds et al. 2007) are used to display the development of IOB, which are derived by linear interpolation of the weekly OI version 2 fields to daily fields then averaging the daily values over a month. The SST fields are available on $1^{\circ}$ spatial resolution from December 1981 to the present. The monthly gridded temperature fields from Roemmich-Gilson Argo Climatology (RG Argo; Roemmich and Gilson 2009), with a regular $1^{\circ}$ horizontal resolution and 58 vertical levels in the upper $2000 \mathrm{~m}$, are available from January 2004 to the present. The altimeter satellite grided sea surface height (SSH) data is obtained from Copernicus Marine Environment Monitoring Service (CMEMS), which has a spatial grid resolution of $0.25^{\circ}$ and a temporal resolution of 1 day from January 1993 to the present.

An observation-based merged analysis of precipitation is provided by the Global Precipitation Climatology Project (GPCP) monthly product, which covers the period from January 1979 through the present (Huffman et al. 1997, 2009; Adler et al. 2003). The Levels 3.0 and 3.5 Cross-Calibrated Multi-Platform (CCMP) version 2.0 gridded surface vector winds are produced using satellite, moored buoy, and model wind data since 1988, which are available from Remote Sensing Systems (RSS; Atlas et al. 2011; Wentz et al. 2015). The surface heat fluxes are provided by the fifth generation ECMWF atmospheric reanalysis (ERA5) of the global climate, covering from January 1979 through the present.

The indices of Niño3.4, IOD, and IOB modes were calculated using ERSSTv5 from January 1960 to February 2021. The seasonal cycle and linear trends are removed from the anomalies.

\section{Results}

Over the past 60 years, five warming and one cooling events occurred during the co-occurrence of IOD and ENSO, five (three) warming and four (one) cooling events during the pure (weak) ENSO, and only one warming event occurred during the pure IOD (Fig. 1b). That is 2019 extreme IOD, which forced a TIO basin-wide warming to occur in the following year.

In 2019, the positive IOD developed independently without an El Niño event, which was the strongest event since the 1960s (Doi et al. 2020; Du et al. 2020; Lu and Ren 2020). The 2019 extreme IOD is classified as the "prolonged IOD", which features a longer period of development and decay (Du et al. 2020). It developed during MAM, peaked at SON, and decayed in the following season (Fig. 1a; Du et al. 2020). In SON 2019, a strong SST cooling in the southeast and warming in the west and southwest, with strong equatorial easterly anomalies and anticyclonic wind stress curl anomalies on both sides of the equator, appeared during the mature phase of positive IOD (Fig. 2a, b). A similar dipole pattern of precipitation anomalies was caused by this extreme IOD, with floods along the western coast of TIO and severe drought and bushfires in Indonesia and Australia (Fig. 2a; Bureau of Meteorology, Australian Government 2019; Munthe et al. 2019; OCHA 2019). Meanwhile, the thermocline deepened and SSH rose in the west, while the thermocline shallowed and SSH dropped in the east through the modulation of oceanic planetary waves and zonal heat transport, which were triggered by the equatorial easterly anomalies and anticyclonic wind stress curl anomalies (Fig. 2b; Feng et al. 2001; Vinayachandran et al. 2002; Rao et al. 2002; Nagura and McPhaden 2010).

After the extreme IOD disappeared, the TIO experienced a basin-wide warming from the following spring to summer, with two peaks in March and June, respectively (Figs. 1a, 2c). Correspondingly, an increase in precipitation took place over the TIO in this period (Fig. 2c; Annamalai et al. 2005; Li et al. 2008). Similarly, the thermocline in the TIO displayed a basin-wide deepening in summer, replacing the dipole structure in the 2019 fall (Fig. 2d). The sea surface and thermocline warming in the SWTIO showed more pronounced, with a "C-shaped" surface wind anomaly anchored, indicating the important role of the SWTIO active air-sea coupling processes in the TIO basin-warming (Fig. 2c, d).

Significant westward-propagating oceanic downwelling Rossby waves were found in the south TIO, accompanied by copropagating thermocline and SST warming from the development phase to the decay phase of the 2019 extreme IOD (Fig. 3). The downwelling Rossby waves and corresponding SST warming during 2019-2020 were the strongest on record, forced by sustained anticyclone wind curls associated with the extreme IOD in 2019 (Zhou et al. 2021; Zhang $Y$ et al. 2021). In boreal spring (MAM) of 2019, a positive wind stress curl anomaly occurred in the east, triggering the westward-propagating downwelling Rossby waves via Ekman pumping and convergence (Fig. 3b). The downwelling Rossby waves deepened the thermocline, leading to thermocline warming in the south TIO. Meanwhile, the mixed layer is deepened by the Ekman pumping. During the mature phase (SON) of IOD, the positive wind stress curl anomaly became stronger and covered a larger area over the south TIO, forcing and strengthening the westward-propagating 
(a) SST \& Precip 2019SON

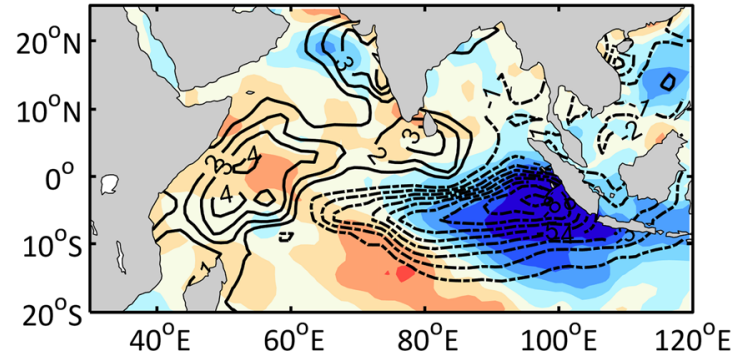

(c) SST \& Precip 2020AM
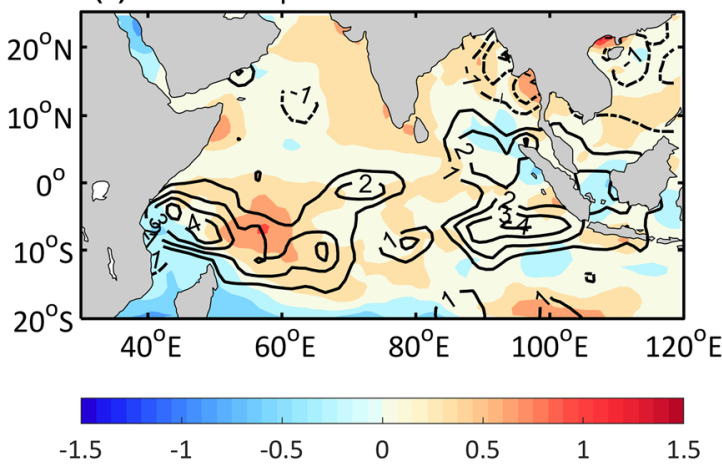

(b) SSH \& Wind 2019SON

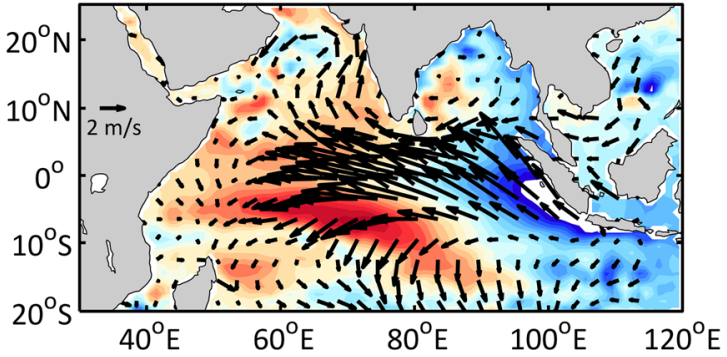

(d) SSH \& Wind 2020AMJ

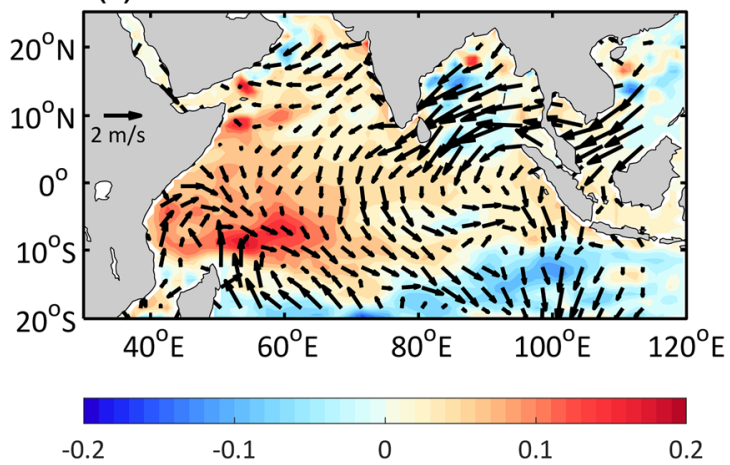

Fig. 2 a SSTa (shading, ${ }^{\circ} \mathrm{C}$ ) and precipitation anomaly (contours, mm/day) in 2019 SON. b SSHa (shading, $\mathrm{m}$ ) and wind anomalies (vectors, m/s) in 2019 SON. c, d same with (a, b), but in 2020 AMJ

downwelling Rossby waves (Fig. 3b). Thus, the thermocline became deeper, and the resultant warming of the thermocline became more significant. Subsequently, the downwelling Rossby wave propagated westward to the thermocline dome in the SWTIO, which deepened the thermocline and caused the SST warming in the SWTIO (Fig. 3c; Chowdary et al. 2009). In DJF, the downwelling Rossby waves and associated thermocline fluctuation reached their peak (Fig. 3d). The SST warming in the SWTIO was maintained by the slow-propagating downwelling Rossby waves and local wind forcing until the 2020 summer (Fig. 3e). This breaks through our previous understanding that SWTIO SST warming cannot persist until the following summer during the pure IOD events.

The SST warming in the SWTIO-induced heavy precipitation by strengthening local deep convection during spring to summer (Fig. 4). Therefore, equatorially antisymmetric SST and convection patterns appeared in the TIO (Fig. 4). Consistently, the surface wind anomalies feature an antisymmetric circulation structure over the TIO (Fig. 4a; Kawamura et al. 2001; Wu et al. 2008; Wu and Yeh 2010). A cross-equatorial "C-shaped" wind anomaly over the TIO, with northeasterlies north and northwesterlies south of the equator, was forced by the north-south temperature gradient and Coriolis effect. In turn, the cross-equatorial "C-shaped" wind anomaly also favored the north-south SST gradient, because surface wind caused less latent heat flux loss over the southern TIO. Thus, in spring, positive WES feedback works in the southern $\mathrm{TIO}$, supporting the maintenance of the antisymmetric mode (Wu et al. 2008; Wu and Yeh 2010). In summer, the anomalous northeasterlies weakened the climatological monsoon southwesterlies over the northern TIO, leading to an increase in SST due to the positive WES feedback mechanism (Fig. 4; Xie and Philander 1994; Du et al. 2009; Chen et al. 2019). Meanwhile, the enhanced precipitation extended to the northern TIO, with the development of SST warming and summer monsoon in the TIO (Fig. 4; Annamalai et al. 2005; Izumo et al. 2008).

In addition, the westward-propagating downwelling Rossby waves in the south TIO transformed into the equatorward-propagating coastal-trapped waves after reaching the western boundary and then reflected as the equatorial Kelvin waves that propagate eastward along the equator (Le Blanc and Boulanger 2001; McPhaden and Nagura 2014; Wang et al. 2016; Chen et al. 2019). Thus, the downwelling Rossby waves and reflected-equatorial Kelvin waves sustained the warming of the western TIO and west-east temperature gradient from 2019 winter to the following spring (Fig. 5a, b; Jury and Huang 2004). In early spring, the west-east temperature gradient forced the equatorial easterly wind anomaly (Figs. 4a, $5 \mathrm{~b}$; Du et al. 2020), which favored the generation of 

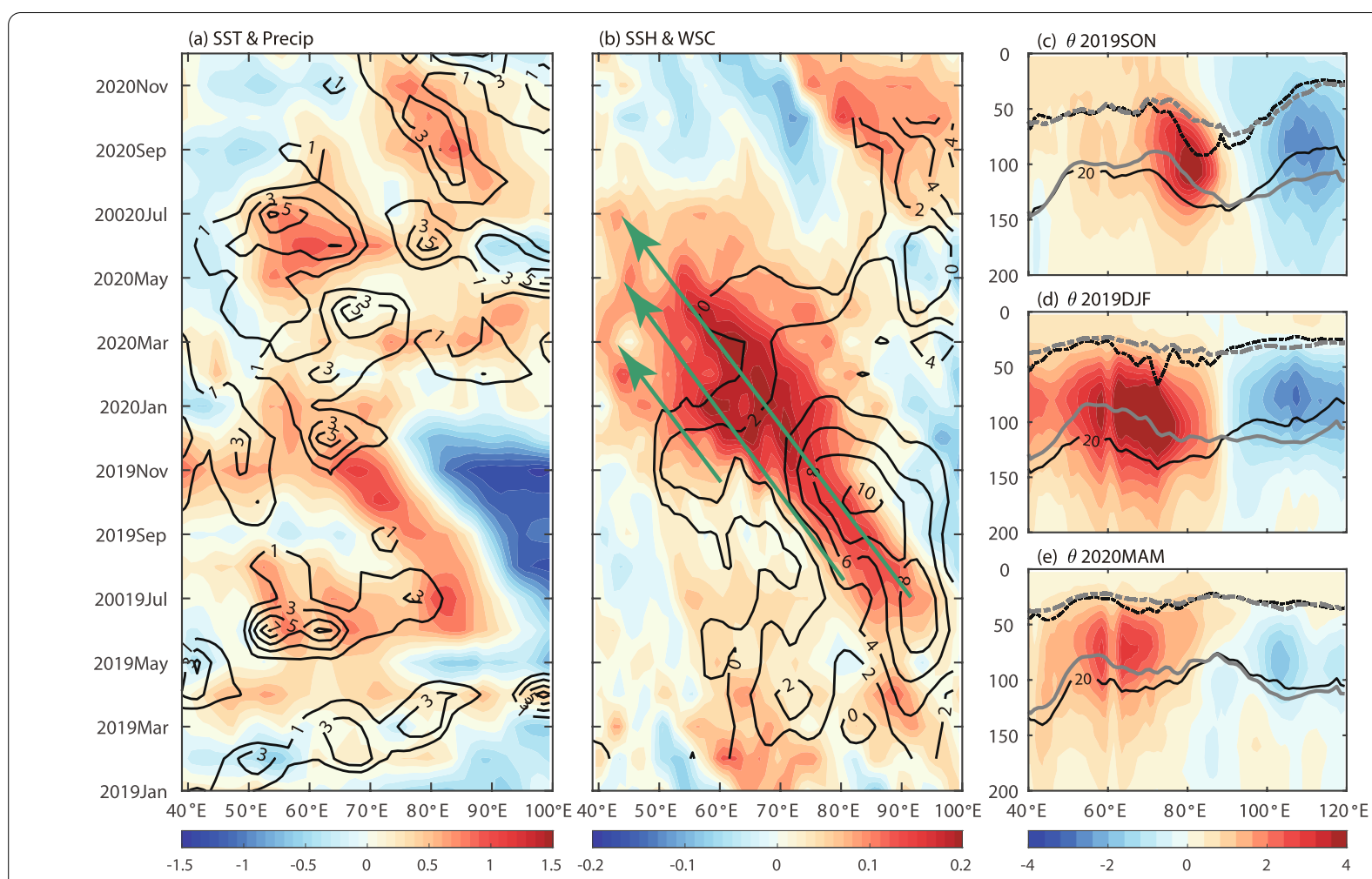

Fig. 3 Hovmöller diagrams of (a) SSTa (shading, ${ }^{\circ} \mathrm{C}$ ) and precipitation anomalies (contours, mm/day), and $\mathbf{b}$ SSHa (shading, $\mathrm{m}$ ) and wind stress curl anomalies (contours, $10^{-8} \mathrm{~N} / \mathrm{m}^{3}$ ) averaged in $8-12^{\circ} \mathrm{S}$. Green arrows denote the westward-propagating Rossby waves. c-e Vertical distribution of potential temperature anomalies (shading, ${ }^{\circ} \mathrm{C}$ ), MLD (black dashed lines), and D20 (solid black lines) averaged between 8 and $12^{\circ} \mathrm{S}$ in $2019 \mathrm{SON}$, 2019 D(2020)JF, 2020 MAM, respectively. Gray lines in c-e are climatological means for the period 2004-2020

downwelling Rossby waves and westward heat advection, further maintaining the warming in the western TIO.

In the eastern TIO, the SST warming was affected by the air-sea interface exchanges associated with cloudradiation-SST feedback and WES feedback, resulting from the weakening of anomalous subsidence of Walker Circulation over the east TIO. During the boreal winter of 2019, a reduction of cloud cover, induced by the cooling pole of IOD off the Sumatran southwest, favored an increase in the shortwave radiation (Figure not shown; Cai and Qiu 2013; Liu et al. 2014). In addition, the strong southeasterly wind anomaly weakened during the decay phase of IOD, resulting in the SST warming due to a decrease in the heat latent flux loss of the ocean (Figs. 4b, 5c; Tokinaga and Tanimoto 2004). In later spring, the reflected-equatorial Kelvin reached the Sumatra-Java coasts, sustaining SST warming in the eastern TIO (Fig. 5a, b). An increase in precipitation followed the SST warming in the eastern TIO (Figs. 2c, 5a).

\section{Summary and discussion}

The TIO experienced a basin-wide warming in 2020, following an extreme and prolonged positive IOD event instead of an El Niño event. This is the first record since the 1960s. Persistent warming occurred in the SWTIO from late 2019 to early 2020, sustained by oceanic downwelling Rossby waves associated with the extreme 2019 IOD via thermocline-SST feedback. During 2020 spring to early summer, the SWTIO warming triggered the equatorially antisymmetric SST, precipitation and surface wind patterns over the TIO. The cross-equatorial "C-shaped" wind anomaly, with northeasterly-northwesterly wind anomaly north-south of the equator, weakened the climatological surface winds then led to basin-wide warming via reducing surface evaporation. Moreover, the westward-propagating Rossby waves reflected as the eastward-propagating equatorial Kelvin waves, which favored the persistence of warming in the western TIO in 2020 spring. In the eastern TIO, air-sea interface exchanges play an important role in SST warming. The importance of air-sea coupling processes associated with the independent and extreme IOD in the TIO basin-warming mode has been clarified in this study, 


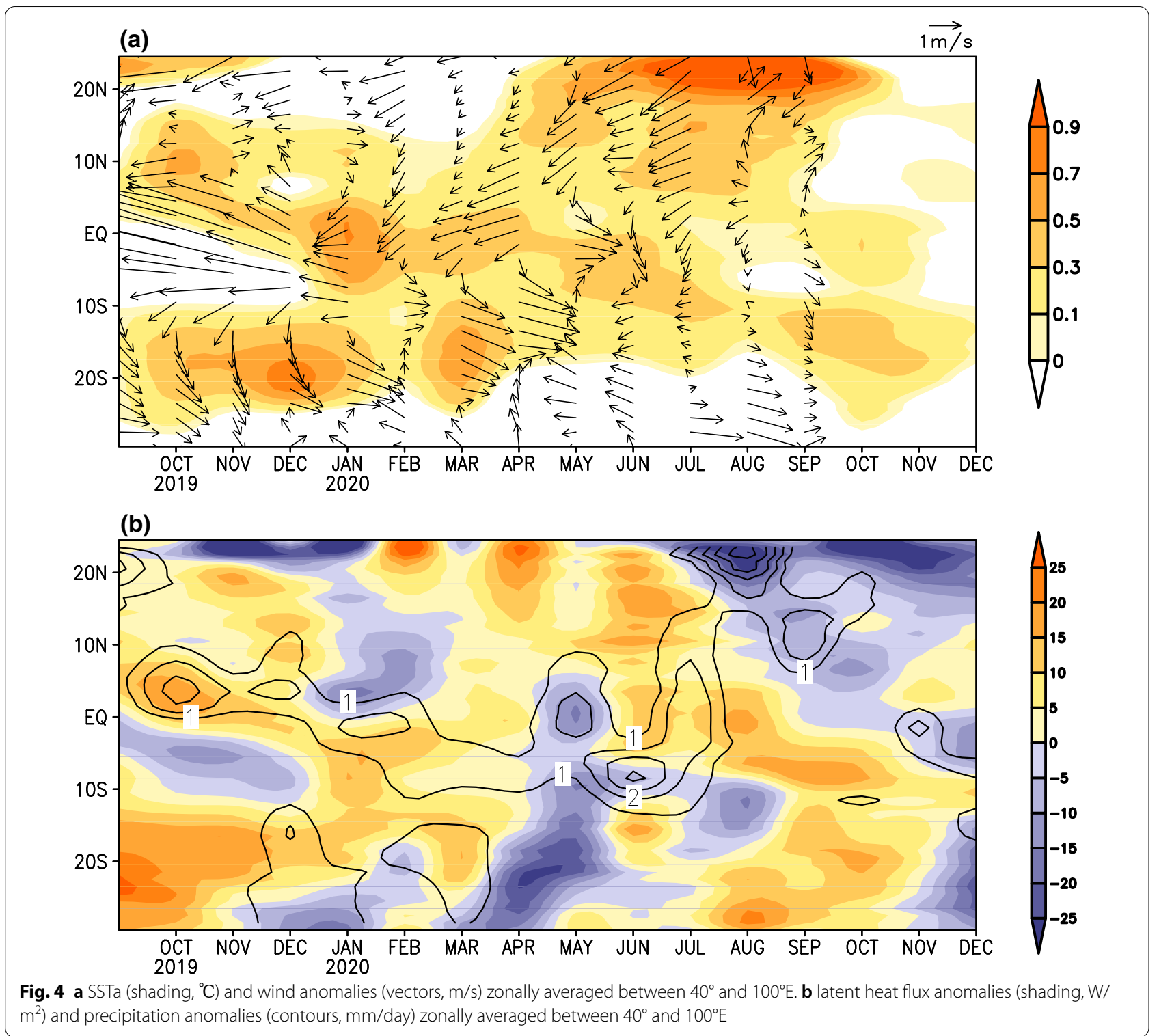

which allows us to rethink the relationship between the Indo-Pacific climate modes.

In addition to the local forcing of the TIO, the remote forcing from the Pacific might also impact the development of IOB warming in 2020. A weak El Niño Modoki developed in the tropical Pacific during 2019. Zhou et al. (2021) suggested that the warming in the central-western tropical Pacific during the weak El Niño Modoki contributed to the sustained anticyclone wind curls over the south TIO in early 2020 according to the results of the atmospheric model experiments. Zhang L et al. (2021) further indicated that the warming of the tropical Pacific contributes to the tropical Indian Ocean wind anomalies, regardless of whether the warming is in the western or eastern tropical Pacific. The tropical Pacific warming causes the Pacific convection center to shift eastward, and then triggers atmospheric Rossby waves over the Indian Ocean, resulting in a pair of lowlevel anomalous anticyclones occurring on both sides of the equator. Nevertheless, our results in this study challenge the perception that only ENSO triggers the IOB. The relationship between ENSO and IOB would change with ocean mean state and ENSO activity on long timescales (Xie et al. 2010; Zheng et al. 2011, 2016; Hu et al. 2013; Tao et al. 2015; Liu et al. 2021). In a warming climate, both extreme positive IOD events and El Niño events are projected to become more frequent (Cai 


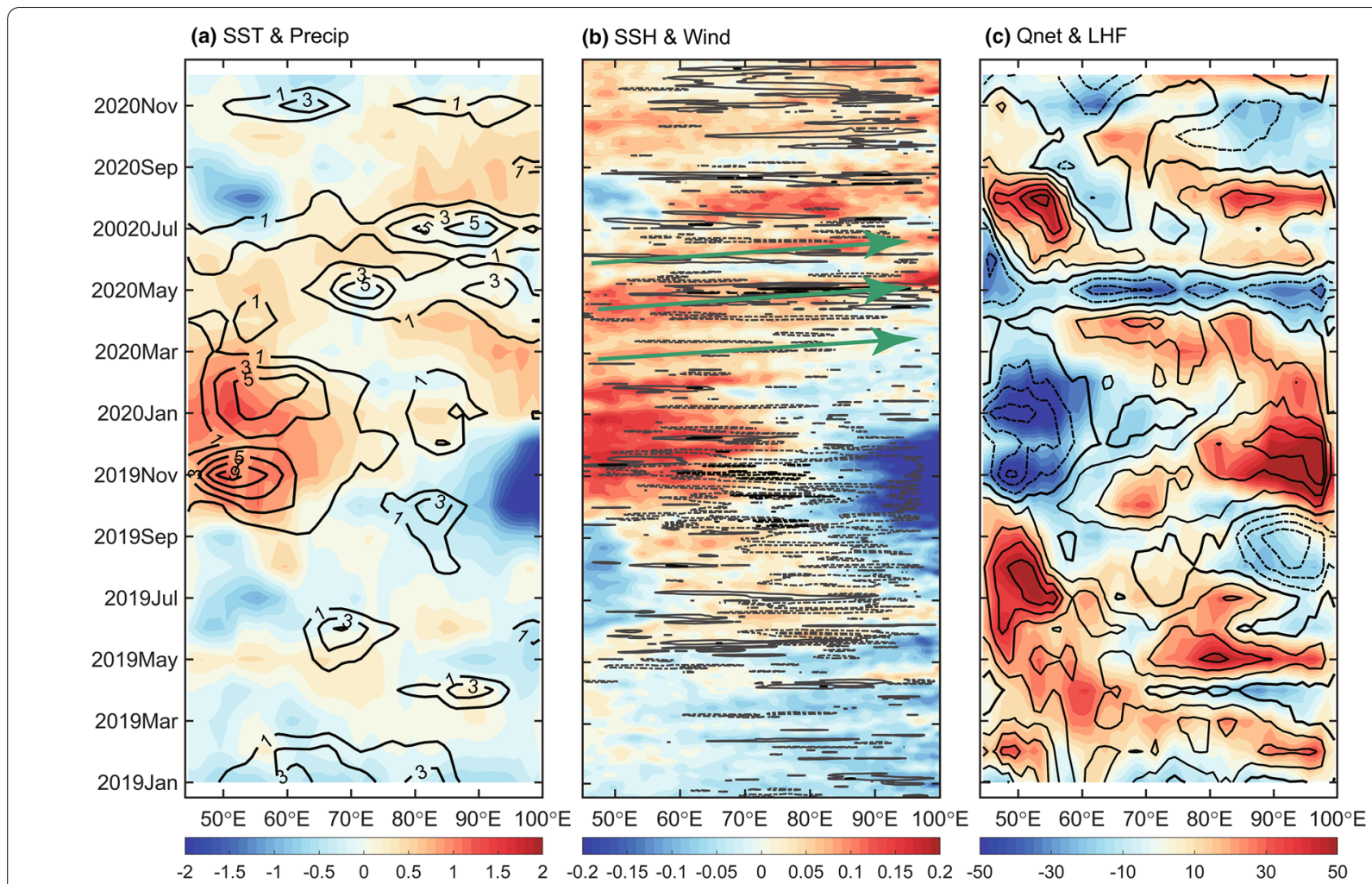

Fig. 5 Hovmöller diagrams of (a) monthly SSTa (shading, ${ }^{\circ} \mathrm{C}$ ) and precipitation anomalies (contours, $\mathrm{mm} /$ day), (b) daily SSHa (shading, $\mathrm{m}$ ) and zonal wind velocity anomalies (contours, $\mathrm{m} / \mathrm{s}$ ), and (c) monthly net air-sea heat flux anomalies (shading, $\mathrm{W} / \mathrm{m}^{2}$ ) and latent heat flux anomalies (contours, $\mathrm{W} / \mathrm{m}^{2}$ ) averaged in $1^{\circ} \mathrm{S}-1^{\circ} \mathrm{N}$. Green arrows in $\mathbf{b}$ denote the eastward-propagating Kelvin waves

et al. 2014; Freund et al. 2020). Thus, it is worth paying attention to changes in the relationship between the Indo-Pacific climate modes, and their relative contributions to climate variability in the Indo-Pacific.

\begin{abstract}
Abbreviations
IOB: Indian Ocean Basin; IOD: Indian Ocean Dipole; ENSO: El Niño-Southern Oscillation; SST: Sea surface temperature; SSH: Sea surface height; SSTa: Sea surface temperature anomaly; SSHa: Sea surface height anomaly; TIO: Tropical Indian Ocean; SWTIO: Southwest tropical Indian Ocean; MAM: March, April and May; SON: September, October and November; DJF: December, January and February.

\section{Acknowledgements}

We thank to two anonymous reviewers for their constructive comments and suggestions. This study is supported by the National Natural Science Foundation of China $(41830538,42090042,42006026)$, the Natural Science Foundation of Guangdong Province, China (2020A1515010361), the Chinese Academy of Sciences (XDA15020901, 133244KYSB20190031, ZDRW-XH-2019-2, XDB42010304, LTOZZ2005, LTOZZ2012), and the Southern Marine Science and Engineering Guangdong Laboratory (Guangzhou) (GML2019ZD0303, 2019BT02H594).
\end{abstract}

\section{Authors' contributions}

YD conceived the study. YZ performed the analysis, generated the figures, and wrote the manuscript. Both authors read and approved the final manuscript.

\section{Funding}

National Natural Science Foundation of China (41830538, 42090042, 42006026); Natural Science Foundation of Guangdong Province, China (2020A1515010361); Chinese Academy of Sciences (XDA15020901, 133244KYSB20190031, ZDRW-XH-2019-2, XDB42010304, LTOZZ2005, LTOZZ2012); Southern Marine Science and Engineering Guangdong Laboratory (Guangzhou) (GML2019ZD0303, 2019BT02H594).

\section{Availability of data and materials}

The OISST monthly fields are provided by https://psl.noaa.gov/data/gridded/ data.noaa.oisst.v2.html. Argo data were collected and made freely available by the International Argo Program and the national programs that contribute to it (http://www.argo.ucsd.edu, http://argo.jcommops.org). The SSH data set is available at https://resources.marine.copernicus.eu/?option=com_csw\& view=details\&product_id=SEALEVEL_GLO_PHY_L4_REP_OBSERVATIONS_ 008_047 and https://resources.marine.copernicus.eu/?option =com_csw\& view=details\&product_id=SEALEVEL_GLO_PHY_L4_NRT_OBSERVATIONS_ 008_046. The ERA5 data set is provided by CMEMS at https://cds.climate.coper nicus.eu/cdsapp\#!/dataset/reanalysis-era5-single-levels-monthly-means?tab= form. The GPCP precipitation is obtained from NASA/GSFC (http://precip.gsfc. nasa.gov). The CCMP surface wind data set is available at https://data.remss. com/ccmp/.

\section{Declarations}

\section{Competing interests}

The authors declare that they have no competing interests. 


\section{Author details}

${ }^{1}$ State Key Laboratory of Tropical Oceanography, South China Sea Institute of Oceanology, Chinese Academy of Sciences, Guangzhou, China. ${ }^{2}$ Southern Marine Science and Engineering Guangdong Laboratory, Guangzhou, China. ${ }^{3}$ University of Chinese Academy of Sciences, Beijing, China.

Received: 31 October 2021 Accepted: 2 December 2021 Published online: 20 December 2021

\section{References}

Adler RF, Huffman GJ, Chang A, Ferraro R, Xie PP, Janowiak J et al (2003) The version-2 global precipitation climatology project (GPCP) monthly precipitation analysis (1979-present). J Hydrometeorol 4(6):1147-1167

Alexander MA, Bladé I, Newman M, Lanzante JR, Lau NC, Scott JD (2002) The atmospheric bridge: the influence of ENSO teleconnections on air-sea interaction over the global oceans. J Clim 15(16):2205-2231

Annamalai H, Liu P, Xie SP (2005) Southwest Indian Ocean SST variability: its local effect and remote influence on Asian monsoons. J Clim 18(20):4150-4167

Atlas R, Hoffman RN, Ardizzone J, Leidner SM, Jusem JC, Smith DK, Gombos D (2011) A cross-calibrated, multiplatform ocean surface wind velocity product for meteorological and oceanographic applications. Bull Am Meteor Soc 92(2):157-174

Behera SK, Salvekar PS, Yamagata T (2000) Simulation of interannual SST variability in the tropical Indian Ocean. J Clim 13(19):3487-3499

Bureau of Meteorology, Australian Government (2019) Special Climate Statement 71 - severe fire weather conditions in southeast Queensland and northeast New South Wales in September 2019. Retrieved from http:// www.bom.gov.au/climate/current/specialstatements.shtm

Cai W, Qiu Y (2013) An observation-based assessment of nonlinear feedback processes associated with the Indian Ocean dipole. J Clim 26(9):2880-2890

Cai W, Santoso A, Wang G, Weller E, Wu L, Ashok K et al (2014) Increased frequency of extreme Indian Ocean Dipole events due to greenhouse warming. Nature 510(7504):254-258

Chakravorty S, Chowdary JS, Gnanaseelan C (2013) Spring asymmetric mode in the tropical Indian Ocean: role of El Niño and IOD. Clim Dyn 40(5-6):1467-1481

Chakravorty S, Gnanaseelan C, Chowdary JS, Luo JJ (2014) Relative role of El Niño and IOD forcing on the southern tropical Indian Ocean Rossby waves. J Geophys Res Oceans 119(8):5105-5122

Chambers DP, Tapley BD, Stewart RH (1999) Anomalous warming in the Indian Ocean coincident with El Niño. J Geophys Res Oceans 104(C2):3035-3047

Chen Z, Du Y, Wen Z, Wu R, Xie SP (2019) Evolution of south tropical Indian Ocean warming and the climatic impacts following strong El Niño events. J Clim 32(21):7329-7347

Chowdary JS, Gnanaseelan C (2007) Basin-wide warming of the Indian Ocean during El Niño and Indian Ocean dipole years. Int J Climatol J Roy Meteorolog Soc 27(11):1421-1438

Chowdary JS, Gnanaseelan C, Xie SP (2009) Westward propagation of barrier layer formation in the 2006-07 Rossby wave event over the tropical southwest Indian Ocean. Geophys Res Lett 36(4).

Chowdary JS, Patekar D, Srinivas G, Gnanaseelan C, Parekh A (2019) Impact of the Indo-Western Pacific Ocean capacitor mode on South Asian summer monsoon rainfall. Clim Dyn 53(3):2327-2338

Doi T, Behera SK, Yamagata T (2020) Predictability of the super IOD event in 2019 and its link with El Niño Modoki. Geophys Res Lett 47(7) e2019GL086713

Du Y, Xie SP, Huang G, Hu K (2009) Role of air-sea interaction in the long persistence of El Niño-induced north Indian Ocean warming. J Clim 22(8):2023-2038

Du Y, Yang L, Xie SP (2011) Tropical Indian Ocean influence on northwest Pacific tropical cyclones in summer following strong El Niño. J Clim 24(1):315-322

Du Y, Xie SP, Yang YL, Zheng XT, Liu L, Huang G (2013) Indian Ocean variability in the CMIP5 multimodel ensemble: the basin mode. J Clim 26(18):7240-7266
Du Y, Zhang Y, Zhang LY, Tozuka T, Ng B, Cai W (2020) Thermocline warming induced extreme Indian Ocean Dipole in 2019. Geophys Res Lett 47(18):e2020GL090079

Du Y, Chen Z, Zhang Y, Hu K, Zheng X, Yu W (2021) Influence of South Tropical Indian Ocean dynamics on the Indian summer monsoon. In: Indian Summer Monsoon Variability. Elsevier, pp. 183-196

Feng M, Meyers G, Wijffels S (2001) Interannual upper ocean variability in the tropical Indian Ocean. Geophys Res Lett 28(21):4151-4154

Freund MB, Brown JR, Henley BJ, Karoly DJ, Brown JN (2020) Warming patterns affect El Niño diversity in CMIP5 and CMIP6 models. J Clim 33(19):8237-8260

Guo F, Liu Q, Yang J, Fan L (2018) Three types of Indian Ocean basin modes. Clim Dyn 51(11):4357-4370

Hermes JC, Reason CJC (2008) Annual cycle of the South Indian Ocean (Seychelles-Chagos) thermocline ridge in a regional ocean model. J Geophys Res Oceans 113(C4)

Hong CC, Li T, Chen YC (2010) Asymmetry of the Indian Ocean basinwide SST anomalies: roles of ENSO and IOD. J Clim 23(13):3563-3576

Hu J, Duan A (2015) Relative contributions of the Tibetan Plateau thermal forcing and the Indian Ocean Sea surface temperature basin mode to the interannual variability of the East Asian summer monsoon. Clim Dyn 45(9):2697-2711

Hu K, Huang G, Huang R (2011) The impact of tropical Indian Ocean variability on summer surface air temperature in China. J Clim 24(20):5365-5377

Hu K, Huang G, Qu X, Huang R (2012) The impact of Indian Ocean variability on high temperature extremes across the southern Yangtze River valley in late summer. Adv Atmos Sci 29(1):91-100

Hu K, Huang G, Wu R (2013) A strengthened influence of ENSO on August high temperature extremes over the southern Yangtze River valley since the late 1980s. J Clim 26(7):2205-2221

Huang B, Kinter JL III (2002) Interannual variability in the tropical Indian Ocean. J Geophys Res Oceans 107(C11):20-21

Huang G, Qu X, Hu K (2011) The impact of the tropical Indian Ocean on South Asian high in boreal summer. Adv Atmos Sci 28(2):421-432

Huang G, Hu KM, Qu X, Tao WC, Yao SL, Zhao GJ, Jiang WP (2016) A review about Indian Ocean basin mode and its impacts on East Asian summer climate. Chin J Atmos Sci 40:121-130

Huffman GJ, Adler RF, Arkin P, Chang A, Ferraro R, Gruber A et al (1997) The global precipitation climatology project (GPCP) combined precipitation dataset. Bull Am Meteor Soc 78(1):5-20

Huffman GJ, Adler RF, Bolvin DT, Gu G (2009) Improving the global precipitation record: GPCP version 2.1. Geophys Res Lett 36(17)

Izumo T, Montégut CB, Luo JJ, Behera SK, Masson S, Yamagata T (2008) The role of the western Arabian Sea upwelling in Indian monsoon rainfall variability. J Clim 21(21):5603-5623

Jury MR, Huang B (2004) The Rossby wave as a key mechanism of Indian Ocean climate variability. Deep Sea Res Part I 51(12):2123-2136

Kawamura R, Matsuura T, lizuka S (2001) Role of equatorially asymmetric sea surface temperature anomalies in the Indian Ocean in the Asian summer monsoon and El Niño-Southern Oscillation coupling. J Geophys Res Atmos 106(D5):4681-4693

Klein SA, Soden BJ, Lau NC (1999) Remote sea surface temperature variations during ENSO: evidence for a tropical atmospheric bridge. J Clim 12(4):917-932

Lau NC, Nath MJ (1996) The role of the "atmospheric bridge" in linking tropical Pacific ENSO events to extratropical SST anomalies. J Clim 9(9):2036-2057

Le Blanc JL, Boulanger JP (2001) Propagation and reflection of long equatorial waves in the Indian Ocean from TOPEX/POSEIDON data during the 1993-1998 period. Clim Dyn 17(7):547-557

Li S, Lu J, Huang G, Hu K (2008) Tropical Indian Ocean basin warming and East Asian summer monsoon: a multiple AGCM study. J Clim 21(22):6080-6088

Liu L, Xie SP, Zheng XT, Li T, Du Y, Huang G, Yu WD (2014) Indian Ocean variability in the CMIP5 multi-model ensemble: the zonal dipole mode. Clim Dyn 43(5-6):1715-1730

Liu F, Zhang W, Jin FF, Hu S (2021) Decadal Modulation of the ENSO-Indian Ocean Basin Warming Relationship during the Decaying Summer by the Interdecadal Pacific Oscillation. J Clim 34(7):2685-2699

Lu B, Ren HL (2020) What caused the extreme Indian Ocean Dipole event in 2019? Geophys Res Lett 47(11):e2020GL087768 
Masumoto Y, Meyers G (1998) Forced Rossby waves in the southern tropical Indian Ocean. J Geophys Res Oceans 103(C12):27589-27602

McPhaden MJ, Nagura M (2014) Indian Ocean dipole interpreted in terms of recharge oscillator theory. Clim Dyn 42(5-6):1569-1586

Munthe BC, Nangoy F, Schmollinger C (2019) Area burned in 2019 forest fires in Indonesia exceeds 2018-Official, Jakarta (Reuters). Retrieved from https://www.reuters.com/article/us-southeast-asia-haze/area-burned-in2019-forest-fires-in-indonesiaexceeds-2018-official-idUSKBN1X00VU

Murtugudde R, Busalacchi AJ (1999) Interannual variability of the dynamics and thermodynamics of the tropical Indian Ocean. J Clim 12(8):2300-2326

Murtugudde R, McCreary JP Jr, Busalacchi AJ (2000) Oceanic processes associated with anomalous events in the Indian Ocean with relevance to 1997-1998. J Geophys Res Oceans 105(C2):3295-3306

Nagura M, McPhaden MJ (2010) Dynamics of zonal current variations associated with the Indian Ocean dipole. J Geophys Res Oceans 115(C11)

Neelin JD, Battisti DS, Hirst AC, Jin FF, Wakata Y, Yamagata T, Zebiak SE (1998) ENSO theory. J Geophys Res Oceans 103(C7):14261-14290

OCHA (2019) Eastern Africa region: regional flood snapshot (November 2019), UN Office for the Coordination of Humanitarian Affairs. Retrieved from https://reliefweb.int/report/south-sudan/eastern-africa-region-regionalflood-snapshot-november-2019

Rao SA, Behera SK, Masumoto Y, Yamagata T (2002) Interannual subsurface variability in the tropical Indian Ocean with a special emphasis on the Indian Ocean dipole. Deep Sea Res Part I| 49(7-8):1549-1572

Reason CJC, Allan RJ, Lindesay JA, Ansell TJ (2000) ENSO and climatic signals across the Indian Ocean basin in the global context: Part I, Interannual composite patterns. Int J Climatol J Roy Meteorol Soc 20(11):1285-1327

Reynolds RW, Smith TM, Liu C, Chelton DB, Casey KS, Schlax MG (2007) Daily high-resolution-blended analyses for sea surface temperature. I Clim 20(22):5473-5496

Roemmich D, Gilson J (2009) The 2004-2008 mean and annual cycle of temperature, salinity, and steric height in the global ocean from the Argo Program. Prog Oceanogr 82(2):81-100

Takaya Y, Ishikawa I, Kobayashi C, Endo H, Ose T (2020) Enhanced Meiyu-Baiu rainfall in early summer 2020: aftermath of the 2019 super IOD event. Geophys Res Lett 47(22):e2020GL090671

Tao W, Huang G, Hu K, Qu X, Wen G, Gong H (2015) Interdecadal modulation of ENSO teleconnections to the Indian Ocean Basin Mode and their relationship under global warming in CMIP5 models. Int I Climatol 35(3):391-407

Tokinaga H, Tanimoto Y (2004) Seasonal transition of SST anomalies in the tropical Indian Ocean during El Niño and Indian Ocean dipole years. J Meteorol Soc Japan Ser II 82(4):1007-1018

Tozuka T, Yokoi T, Yamagata T (2010) A modeling study of interannual variations of the Seychelles Dome. J Geophys Res Oceans 115(C4)

Vinayachandran PN, lizuka S, Yamagata T (2002) Indian Ocean dipole mode events in an ocean general circulation model. Deep Sea Res Part II 49(7-8):1573-1596

Wang H, Murtugudde R, Kumar A (2016) Evolution of Indian Ocean dipole and its forcing mechanisms in the absence of ENSO. Clim Dyn 47(7):2481-2500

Wentz FJ, Scott J, Hoffman R, Leidner M, Atlas R, Ardizzone J (2015) Remote sensing systems Cross-Calibrated Multi-Platform (CCMP) 6-hourly ocean vector wind analysis product on 0.25 deg grid, Version 2.0. Santa Rosa, CA: Remote Sensing Systems. Retrieved from www.remss.com/measu rements/ccmp

Wu R, Yeh SW (2010) A further study of the tropical Indian Ocean asymmetric mode in boreal spring. J Geophys Res Atmos 115(D8)

Wu R, Kirtman BP, Krishnamurthy V (2008) An asymmetric mode of tropical Indian Ocean rainfall variability in boreal spring. J Geophys Res Atmos 113(D5)

Xie SP, Philander SGH (1994) A coupled ocean-atmosphere model of relevance to the ITCZ in the eastern Pacific. Tellus A 46(4):340-350

Xie SP, Annamalai H, Schott FA, McCreary JP Jr (2002) Structure and mechanisms of South Indian Ocean climate variability. J Clim 15(8):864-878

Xie SP, Hu K, Hafner J, Tokinaga H, Du Y, Huang G, Sampe T (2009) Indian Ocean capacitor effect on Indo-western Pacific climate during the summer following El Niño. J Clim 22(3):730-747
Xie SP, Du Y, Huang G, Zheng XT, Tokinaga H, Hu K, Liu Q (2010) Decadal shift in El Niño influences on Indo-Western Pacific and East Asian climate in the 1970s*. J Clim 23(12):3352-3368. https://doi.org/10.1175/2010JCLI3429.1 Xie SP, Kosaka Y, Du Y, Hu K, Chowdary JS, Huang G (2016) Indo-western Pacific Ocean capacitor and coherent climate anomalies in post-ENSO summer: a review. Adv Atmos Sci 33(4):411-432

Yang J, Liu Q, Xie SP, Liu Z, Wu L (2007) Impact of the Indian Ocean SST basin mode on the Asian summer monsoon. Geophys Res Lett 34(2)

Yokoi T, Tozuka T, Yamagata T (2008) Seasonal variation of the Seychelles Dome. J Clim 21(15):3740-3754

Yu JY, Lau KM (2005) Contrasting Indian Ocean SST variability with and without ENSO influence: a coupled atmosphere-ocean GCM study. Meteorol Atmos Phys 90(3):179-191

Yu W, Xiang B, Liu L, Liu N (2005) Understanding the origins of interannual thermocline variations in the tropical Indian Ocean. Geophys Res Lett 32(24)

Zhang L, Han W, Hu ZZ (2021) Interbasin and Multiple-Time-Scale Interactions in Generating the 2019 Extreme Indian Ocean Dipole. J Clim 34(11):4553-4566

Zhang Y, Du Y, Feng M, Hu S (2021) Long-lasting marine heatwaves instigated by ocean planetary waves in the tropical Indian Ocean during 2015-2016 and 2019-2020. Geophys Res Lett 48(21):e2021GL095350. https://doi. org/10.1029/2021GL095350

Zheng XT, Xie SP, Liu Q (2011) Response of the Indian Ocean basin mode and its capacitor effect to global warming. J Clim 24(23):6146-6164

Zheng XT, Gao L, Li G, Du Y (2016) The southwest Indian Ocean thermocline dome in CMIP5 models: historical simulation and future projection. Adv Atmos Sci 33(4):489-503

Zhou ZQ, Xie SP, Zhang R (2021) Historic Yangtze flooding of 2020 tied to extreme Indian Ocean conditions. Proc Nat Acad Sci 118(12):e2022255118

\section{Publisher's Note}

Springer Nature remains neutral with regard to jurisdictional claims in published maps and institutional affiliations.

\section{Submit your manuscript to a SpringerOpen ${ }^{\circ}$ journal and benefit from:}

- Convenient online submission

- Rigorous peer review

- Open access: articles freely available online

- High visibility within the field

- Retaining the copyright to your article

Submit your next manuscript at $\boldsymbol{\Delta}$ springeropen.com 